\title{
A Japanese single-center experience of the efficacy and safety of enzyme replacement therapy in childhood-onset hypophosphatasia
}

\section{Yohei Sugiyama}

Chiba Children's Hospital: Chiba-ken Kodomo Byoin

Taijiro Watanabe

Chiba Children's Hospital: Chiba-ken Kodomo Byoin

Makiko Tajika

Chiba Children's Hospital: Chiba-ken Kodomo Byoin

Tetsuro Matsuhashi

Chiba Children's Hospital: Chiba-ken Kodomo Byoin

Masaru Shimura

Chiba Children's Hospital: Chiba-ken Kodomo Byoin

Takuya Fushimi

Chiba Children's Hospital: Chiba-ken Kodomo Byoin

Keiko Ichimoto

Chiba Children's Hospital: Chiba-ken Kodomo Byoin

Ayako Matsunaga

Chiba Children's Hospital: Chiba-ken Kodomo Byoin

Tomohiro Ebihara

Chiba Children's Hospital: Chiba-ken Kodomo Byoin

Tomoko Tsuruoka

Chiba Children's Hospital: Chiba-ken Kodomo Byoin

Tomoyuki Akiyama

Okayama University of Science: Okayama Rika Daigaku

Kei Murayama ( $\nabla$ kmuraya@mri.biglobe.ne.jp)

Chiba Children's Hospital https://orcid.org/0000-0002-3923-8636

\section{Research}

Keywords: alkaline phosphatase, asfotase alfa, enzyme replacement therapy, hypophosphatasia

Posted Date: August 3rd, 2021

DOI: https://doi.org/10.21203/rs.3.rs-718059/v1

License: (1) This work is licensed under a Creative Commons Attribution 4.0 International License. Read Full License 


\section{Abstract}

Background

Hypophosphatasia (HPP) is a rare inherited metabolic disorder caused by mutations in the ALPL gene, which encodes tissue nonspecific alkaline phosphatase. The phenotype of HPP is widely diverse from the perinatal severe form to the adult mild form. The former represents the most severe form and was earlier associated with high mortality due to impaired development of the lungs and severe hypomineralization of the bones. Enzyme replacement therapy (ERT) using asfotase alfa was approved in 2015 in Japan for treating patients with HPP and has improved their pulmonary function and life prognosis. There are several practical and ethical challenges related to using orphan drugs for a rare disorder in a publicly funded healthcare system. Sharing experiences about their application is essential towards formulating guidelines to assist clinicians with decisions about their initiation and withdrawal. We report the details of ERT experience in ten cases of childhood-onset HPP in nine families from January 2015 to November 2019 (median [interquartile range] age 11.0 years [7.6-12.5] years; $60 \%$ male). This is the largest study of a single-center cohort describing the clinical course of HPP patients treated with ERT in Asia.

Results

One case of perinatal lethal form of HPP, two cases of perinatal benign form, six cases of childhood form, and one case of odontohypophophatasia were observed. The most common symptom at onset was bone abnormalities. All patients had low serum ALP levels as compared to the age-matched reference range before the commencement of ERT. All HPP patients responded to ERT without serious adverse effects. Genetic analysis showed that eight out of ten patients had compound heterozygosity; two patients had only one heterozygous variant. In this study, two patients had a heterozygous variant of ALPL and responded to ERT, although the variants did not have the dominant-negative effect.

\section{Conclusions}

ERT may be effective in patients with symptoms of HPP even with only one pathogenic variant of ALPL without dominant-negative effect. Early diagnosis based on symptoms such as bone abnormalities or low serum alkaline phosphatase levels might be essential for early treatment and can contribute to better prognosis.

\section{Background}

Hypophosphatasia (HPP) is a genetic disorder caused by defects in tissue-nonspecific alkaline phosphatase (TNSALP) [1]. The loss-of-function mutations in the ALPL gene, located in the short arm of chromosome 1, consisting of 12 exons, and encoding TNSALP, results in HPP [2]. ALPL variants occur in all exons. Depletion of TNSALP causes accumulation of phosphoethanolamine (PEA), pyridoxal 5' phosphate (PLP), and inorganic pyrophosphate. TNSALP dephosphorylates PLP into pyridoxal (PL) [3]. The central pathogenesis of HPP is impaired bone calcification, but the mechanism by which reduced TNSALP activity leads to hypocalcification is not yet fully understood [4]. TNSALP produces inorganic phosphate by degrading pyrophosphate, a calcification inhibitor. The inorganic phosphate produced is taken up into the matrix vesicles released from osteoblasts. In HPP, it is thought that the accumulation of pyrophosphate and the decrease in local phosphorus concentration due to the decreased activity of TNSALP causes hypocalcification.

Patients with HPP have varied clinical manifestations and are classified as having one of the six forms (perinatal lethal, perinatal benign, infantile, childhood, adult, and odontohypophosphatasia) based on the age of onset and severity $[1,5,6]$. There is a Japanese clinical practice guideline to diagnose patients with HPP [7]. HPP has diverse symptoms, such as hypocalcification of the whole body, seizures, poor body weight gain, and premature deciduous tooth loss due to decrement in serum alkaline phosphate (ALP) levels [8]. A low ALP level is important for the diagnosis of HPP. A confirmed diagnosis can be made by genetic testing of the $A L P L$ gene $[7,9]$. Most HPP families have autosomal recessive inheritance, while there are also families with autosomal dominant inheritance. The incidence of severe phenotypes in Japan is approximately 1 in 150,000, whereas the incidence of other phenotypes is unclear [7]. In Japan, the common $A L P L$ variants are c.1559delT and c.979T > C. The prevalence of the c.1559delT allele is approximately 1/480 [6]. Genetic carriers of HPP are usually asymptomatic, although some are mildly symptomatic. Severe phenotypes are recessively inherited, whereas moderate phenotypes are either recessively or dominantly inherited. Furthermore, it is observed that the more severe the disease, the more often it is subject to recessive inheritance [10].

Enzyme replacement therapy (ERT) using asfotase alfa has been approved in many countries, including the United States, the European Union, Canada, and Japan. A Japanese clinical trial has demonstrated the efficacy of ERT in treating patients with HPP [11]. There were 13 patients in this trial with HPP: six with perinatal lethal form, five with infantile form, one with childhood form, and one with adult form of HPP. In Japan, asfotase alfa is covered by health insurance and there is a guideline in place for its use as an established treatment protocol in patients with HPP, facilitating its accessibility and availability to healthcare professionals and patients living with HPP as compared with these in other countries that do not provide insurance coverage for this treatment [7]. A literature search revealed a dearth of published reports describing the clinical course of the childhood form of HPP after ERT. Factors that influence the prognosis and treatment outcome of ERT are unknown, and when and how to declare treatment "non-response" is unclear. Therefore, it is necessary to share experiences from various centers to generalize the applicability of this novel pharmacotherapy for HPP. Thus, we present a case series of childhood-onset HPP and report our experience in treating patients of mild HPP, particularly the childhood form, with ERT at our center.

\section{Methods}

All HPP patients who visited Chiba Children's Hospital, Japan, between January 2015 and November 2019, were included in this study. The diagnosis of HPP was established on the basis of the criteria laid down by the Japanese Clinical Practice Guidelines for hypophosphatasia [7]. The guidelines define primary clinical symptoms of bone mineralization disorder and premature loss of deciduous teeth and primary laboratory findings such as low serum ALP levels 
compared with age-specific normal values [12]. If one or more primary symptoms are seen on clinical examination and a low serum ALP level is observed, HPP should be suspected, and gene testing should be performed for definitive diagnosis. ALPL gene analysis was performed with informed consent. Ten children ( 4 girls and 6 boys) of 9 families were included. The demographic characteristics, clinical features, laboratory investigations, and genetic analysis of all patients are summarized in Table 1. The reference values for serum PLP, PL, and PLP/PL were determined based on a study published by Akiyama et al [13]. Short stature was defined as a height of -2 SD below the mean for a respective age as specified by the 2000 growth survey on BMI for age references for Japanese children (cross-sectional national survey data by the Japanese Ministry of Health, Labour and Welfare, and the Ministry of Education, Culture, Sports, Science and Technology) [14, 15]. ERT using asfotase alfa was administered subcutaneously three times a week at a dose of $2 \mathrm{mg} / \mathrm{kg}$ or six times a week at a dose of $1 \mathrm{mg} / \mathrm{kg}$, and the maximum volume of a single injection was $1 \mathrm{~mL}$ (40 or $100 \mathrm{mg} / \mathrm{mL}$ concentration). This was an observational retrospective patient report that did not involve any research-based patient intervention. All diagnostic procedures and treatment protocols were based on established protocols intended to diagnose and treat patients and adhered to the principles of the Declaration of Helsinki 1975, as revised in 2000. The assay of pyridoxal phosphate and pyridoxal was approved by the Research Ethics Board at Okayama University Hospital (Approval No. 1603-012). 
Table 1

Demographic characteristics, clinical features, laboratory investigation, and genetic analysis of patients

\begin{tabular}{|c|c|c|c|c|c|c|c|c|c|c|c|c|}
\hline Case & $\begin{array}{l}\text { Clinical } \\
\text { form of } \\
\text { HPP }\end{array}$ & Sex & $\begin{array}{l}\text { Age } \\
\text { at } \\
\text { onset } \\
\text { of } \\
\text { HPP }\end{array}$ & $\begin{array}{l}\text { Symptom } \\
\text { at } \\
\text { first onset }\end{array}$ & $\begin{array}{l}\text { Age at ERT } \\
\text { introduction }\end{array}$ & $\begin{array}{l}\text { Age at } \\
\text { last } \\
\text { follow- } \\
\text { up }\end{array}$ & $\begin{array}{l}\text { ALP } \\
\text { before } \\
\text { ERT } \\
\text { (Lower } \\
\text { limit of } \\
\text { standard } \\
\text { value by } \\
\text { age) }\end{array}$ & $\begin{array}{l}\text { Genetic variants } \\
\text { (NM_000478.6) }\end{array}$ & $\begin{array}{l}\text { Family } \\
\text { history } \\
\text { of } \\
\text { HPP }\end{array}$ & $\begin{array}{l}\text { Orthopedic } \\
\text { findings } \\
\text { on X-ray }\end{array}$ & $\begin{array}{l}\text { Renal } \\
\text { calcification }\end{array}$ & Pain \\
\hline 1 & Childhood & $M$ & $2 y$ & Foot pain & 5 y $0 \mathrm{~m}$ & $\begin{array}{l}7 \text { y } 0 \\
\mathrm{~m}\end{array}$ & $\begin{array}{l}197(< \\
430) \\
\text { IU/L }\end{array}$ & $\begin{array}{l}\text { c.613G >A } \\
\text { (p.Ala205Thr) } \\
\text { /c.1559delT } \\
\text { (p.Leu520fs) }\end{array}$ & - & ? & N.C. & ( \\
\hline 2 & Childhood & $\mathrm{F}$ & $\begin{array}{l}0 \text { y } 6 \\
m\end{array}$ & $\begin{array}{l}\text { Poor } \\
\text { weight } \\
\text { gain }\end{array}$ & 10 y $1 \mathrm{~m}$ & $\begin{array}{l}12 \text { y } 0 \\
\mathrm{~m}\end{array}$ & $\begin{array}{l}400(< \\
470) \\
\text { IU/L }\end{array}$ & $\begin{array}{l}\text { c.984_986delCTT } \\
\text { (p.Phe327del) } \\
\text { Heterozygous } \\
\text { variant }\end{array}$ & - & - & - & ( \\
\hline 3 & Childhood & $M$ & $1 \mathrm{y}$ & $\begin{array}{l}\text { Premature } \\
\text { loss of } \\
\text { deciduous } \\
\text { tooth }\end{array}$ & 1 y $5 \mathrm{~m}$ & $\begin{array}{l}3 \text { y } 2 \\
m\end{array}$ & $\begin{array}{l}79(< \\
395) \\
\text { IU/L }\end{array}$ & $\begin{array}{l}\text { c. } 526 \mathrm{G}>\mathrm{A} \\
\text { (p.Ala176Thr)/ } \\
\text { c.920C > T } \\
\text { (p.Pro307Leu) }\end{array}$ & - & ? & - & - \\
\hline 4 & Childhood & $M$ & $\begin{array}{l}9 \mathrm{y} \\
10 \mathrm{~m}\end{array}$ & $\begin{array}{l}\text { Pain in } \\
\text { knee and } \\
\text { hip }\end{array}$ & 11 y $5 \mathrm{~m}$ & $\begin{array}{l}12 \text { y } 2 \\
m\end{array}$ & $\begin{array}{l}421(< \\
470) \\
\text { IU/L }\end{array}$ & $\begin{array}{l}\text { c.1559delT } \\
\text { (p.Leu520fs) } \\
\text { Heterozygous } \\
\text { variant }\end{array}$ & - & - & - & ૫ \\
\hline 5 & Childhood & $M$ & $7 y$ & $\begin{array}{l}\text { Short } \\
\text { stature }\end{array}$ & 10 y $4 \mathrm{~m}$ & $\begin{array}{l}12 \text { y } 7 \\
m\end{array}$ & $\begin{array}{l}359(< \\
460) \\
\text { IU/L }\end{array}$ & $\begin{array}{l}\text { c.382G > A } \\
\text { (p.Val128Met) } \\
\text { /c.529G >A } \\
\text { (p.Ala177Thr) }\end{array}$ & ] & Q & - & Q \\
\hline 6 & Childhood & $\mathrm{F}$ & $10 y$ & Knee pain & 17 y $1 \mathrm{~m}$ & $\begin{array}{l}18 \text { y } 7 \\
m\end{array}$ & $\begin{array}{l}135(< \\
130) \\
\text { IU/L }\end{array}$ & $\begin{array}{l}\text { c.382G >A } \\
\text { (p.Val128Met) } \\
\text { /c.529G > A } \\
\text { (p.Ala177Thr) }\end{array}$ & ( & ૫ & - & ૫ \\
\hline 7 & Odonto & $M$ & $\begin{array}{l}4 \text { y } 2 \\
m\end{array}$ & $\begin{array}{l}\text { Premature } \\
\text { loss of } \\
\text { deciduous } \\
\text { tooth }\end{array}$ & 4 y 3 m & $\begin{array}{l}5 \text { y } 2 \\
m\end{array}$ & $\begin{array}{l}113(< \\
430) \\
\text { IU/L }\end{array}$ & $\begin{array}{l}\text { c.572A > G } \\
\text { (p.Glu191Gly) } \\
\text { /c.1559delT } \\
\text { (p.Leu520fs) }\end{array}$ & - & प & - & - \\
\hline 8 & $\begin{array}{l}\text { Perinatal } \\
\text { benign }\end{array}$ & $M$ & $\begin{array}{l}\text { At } \\
\text { birth }\end{array}$ & $\begin{array}{l}\text { Unequal } \\
\text { length of } \\
\text { limbs }\end{array}$ & 16 y $3 \mathrm{~m}$ & $\begin{array}{l}21 \text { y } 1 \\
\mathrm{~m}\end{array}$ & $\begin{array}{l}103(< \\
270) \\
\text { IU/L }\end{array}$ & $\begin{array}{l}\text { c.979T > C } \\
\text { (p.Phe327Leu) } \\
\text { /c1559delT } \\
\text { (p.Leu520fs) }\end{array}$ & - & प & ૫ & - \\
\hline 9 & $\begin{array}{l}\text { Perinatal } \\
\text { benign }\end{array}$ & $\mathrm{F}$ & $\begin{array}{l}\text { At } \\
\text { birth }\end{array}$ & $\begin{array}{l}\text { Bilateral } \\
\text { femur } \\
\text { deformity }\end{array}$ & $\begin{array}{l}1: 4 \text { y } 5 \mathrm{~m} \\
2: 6 \text { y } 3 \mathrm{~m}\end{array}$ & $\begin{array}{l}9 \text { y } 4 \\
m\end{array}$ & $\begin{array}{l}157(< \\
430) \\
\text { IU/L }\end{array}$ & $\begin{array}{l}\text { c.568_570delAAC } \\
\text { (p.Asn190del) } \\
\text { /c.979T > C } \\
\text { (p.Phe327Leu) }\end{array}$ & - & प & 口 & - \\
\hline 10 & $\begin{array}{l}\text { Perinatal } \\
\text { lethal }\end{array}$ & $\mathrm{F}$ & $\begin{array}{l}\text { At } \\
\text { birth }\end{array}$ & $\begin{array}{l}\text { Short } \\
\text { limbs }\end{array}$ & At birth & $\begin{array}{l}2 \text { y } 4 \\
m\end{array}$ & $\begin{array}{l}8(<530) \\
\text { IU/L }\end{array}$ & $\begin{array}{l}\text { c.1333T > C } \\
\text { (p.Ser445Pro) } \\
\\
\text { /c.1559delT } \\
\text { (p.Leu520fs) }\end{array}$ & - & प & N.C. & - \\
\hline
\end{tabular}

Patient 5 is the younger brother of patient 6 .

ALP: alkaline phosphatase, ERT: Enzyme replacement therapy, HPP: Hypophosphatasia, N.C.: Not conducted

\section{Results}

\section{Clinical data of patients with HPP}

Case 1: 7-year-old male patient 
The patient experienced pain in his lower legs at 2 years of age. At 4 years, he had pain in the upper arms and exhibited premature loss of three deciduous teeth. The serum ALP level was $197 \mathrm{IU} / \mathrm{L}$ (reference value for this age: 430-1,200 IU/L). Genetic testing confirmed that he had compound heterozygosity for c.613G > A (p.Ala205Thr) and c.1559delT (p.Leu520fs) of the ALPL gene. We initiated ERT, and there was consequent improvement in his symptoms of pain in the lower extremities and gradual decline in the rate of premature loss of deciduous teeth. The patient's height increased from $103.7 \mathrm{~cm}(-0.8 \mathrm{SD}$ below the mean for his age group as per the 2000 growth survey) [14] to $116.5 \mathrm{~cm}$ (- 0.5 SD) 2 years after the initial presentation.

\section{Case 2: 12-year-old female patient}

The patient had poor weight gain, and her radiographs showed rachitic changes at the ends of the bones of the trunk at 6 months of age. At 1 year of age, she was suspected to have HPP as her serum ALP levels were in the range of $260-380 \mathrm{IU} / \mathrm{L}$ (reference value for this age: $395-1,289 \mathrm{IU} / \mathrm{L}$ ), but she had no other symptoms. Thereafter, her height had been -1.0 to -2.5 SD below the mean for her age group as per the 2000 growth survey [14]. At 8 years of age, she experienced neck pain and lumbago. There were no abnormalities on imaging tests, and HPP was once again suspected. Genetic analysis revealed a heterozygous variant of the ALPL gene, c.984_986delCTT (p.Phe327del). Her father similarly had the same variant and was asymptomatic; therefore, this variant was not thought to be the cause of her symptoms. The patient was rehabilitated and treated with anti-inflammatory drugs. At the age of 10 years, she could not attend school on account of her inability to walk, carry her bag by herself, or play with her friends because of pain in her extremities (Additional File 1). She was referred to our hospital to commence ERT as the serum PLP level was elevated at $164.4 \mathrm{nmol} / \mathrm{L}$ (reference value: $14.5-57.3 \mathrm{nmol} / \mathrm{L}$ ). The pain in her extremities gradually decreased after the introduction of ERT. Approximately 3-4 months after the initiation of ERT, she was able to join an athletic festival without the support of any anti-inflammatory drugs. Six months after ERT initiation, she did not have any difficulty in attending school (Additional File 1).

\section{Case 3: 3-year-old male patient}

The patient lost five deciduous teeth prematurely with roots intact, starting from the first year of his life. He visited a dentist who suspected HPP. He was then referred to our hospital for further investigation and treatment. The serum ALP level was 79 IU/L (reference value for this age: $395-1,339$ IU/L). The $A L P L$ variants of c.526G > A (p.Ala176Thr) and c.920C > T (p.Pro307Leu) were detected. We started treatment with ERT and noticed a decline in the rate of premature loss of deciduous teeth. His height increased from $73.8 \mathrm{~cm}(-2.0$ SD) to $86.9 \mathrm{~cm}(-1.8 \mathrm{SD})$ in 1 year and 7 months after ERT initiation.

\section{Case 4: 12-year-old male patient}

At 9 years of age, the patient complained of pain in the right knee and hip joint and was referred to an orthopedic surgeon. No abnormalities were noted on radiography, and the patient was monitored. Over the next several months, he developed pain in his chest and extremities and was referred to our hospital for a detailed investigation. Blood examination revealed a low serum ALP level of $421 \mathrm{IU} / \mathrm{L}$ (reference value for this age: $470-1,500 \mathrm{IU} / \mathrm{L}$ ). Genetic testing for the ALPL gene exhibited a heterozygous variant of c.1559delT (p.Leu520fs). Based on our experience in treating case 2 of this series, an HPP patient with a heterozygous variant and reactive to ERT, we likewise commenced ERT in case 4 at the age of 11 years. The patient's pain gradually subsided after the introduction of ERT.

\section{Case 5: 12-year-old male patient}

At the age of 7 years, the patient had a short stature at - 2.0 SD as per the 2000 growth survey [14]. A general practitioner performed a blood examination; the serum ALP level was $338 \mathrm{IU} / \mathrm{L}$ (reference value for this age: 450-1,250 IU/L). He was referred to our hospital at the age of 9 years for further examination and treatment. His serum ALP level continued to remain low, and he had developed bilateral ankle pain, which prompted us to perform further examinations. $A L P L$ variants c.382G > A (p.Val128Met) and c.529G > A (p.Ala177Thr) were found, and treatment with ERT was initiated. His height increased from $126.6 \mathrm{~cm}$ ( 1.9 SD) to $142.0 \mathrm{~cm}(-1.4 \mathrm{SD})$ in 2 years and 3 months, and his pain was gradually alleviated after the introduction of ERT.

\section{Case 6: 18-year-old female patient}

This patient, the older sister of patient 5 of this series, experienced left knee pain at the age of 10 years and was treated surgically after a diagnosis of meniscus injury, but the knee pain persisted. She was also diagnosed with scoliosis at 13 years of age, and when she turned 15, her younger brother (Case 5 ) was diagnosed with HPP. Consequently, she was suspected to have the same disease. Blood examination revealed a low serum ALP level of 140 IU/L (reference value for this age: 120 - $570 \mathrm{IU} / \mathrm{L}$ ). Genetic testing showed the same ALPL variants as her brother, which confirmed the diagnosis of HPP. At 16 years of age, she was started on ERT. Her knee pain gradually improved, and she experienced considerably less fatigue in her daily life after the initiation of ERT.

\section{Case 7: 5-year-old male patient}

At 4 years of age, the patient lost a deciduous tooth with the root intact. He was taken to a general practitioner, and his serum ALP level was found to be 116 IU/L (reference value for this age: 430-1,200 IU/L). Thereafter, he was referred to our hospital for further examination and treatment. A genetic test confirmed ALPL variants; c.572A > G (p.Glu 191Gly) and c.1559delT (p.Leu520fs), and the diagnosis of HPP was confirmed. After the initiation of ERT, he did not experience any further premature loss of deciduous teeth.

\section{Case 8: 21-year-old male patient}

At birth, the patient had a shorter right thigh and a shorter right upper arm than the left thigh and left upper arm, respectively. At the age of 2 years, his serum ALP level was $103 \mathrm{IU} / \mathrm{L}$ (reference value of this age: $410-1,250 \mathrm{IU} / \mathrm{L}$ ). Subsequently, a short stature at approximately -2.0 SD as per the 2000 growth survey [14] and periodontal disease were noted. At the age of 8 years, he was referred to our hospital for surgical correction of the difference in the length of his lower legs. When the patient was 15 years old, asfotase alfa was approved in Japan. Therefore, we performed a genetic test before treatment to confirm HPP; $A L P L$ gene variants: c.979T > C (p.Phe327Leu) and c1559delT (p.Leu520fs) were found. Hence, ERT was commenced. After the initiation of ERT, his 6-minute walk test results improved from $420 \mathrm{~m}$ to $560 \mathrm{~m}$, marking a clinical improvement in performance capacity. 


\section{Case 9: 9-year-old female patient}

Fetal ultrasound at 29 weeks of age revealed bilateral femoral deformities. A low serum ALP level ( 96 IU/L; reference value for this age is $530-1,610$ IU/L) at birth and presence of ALPL variants, namely c.568_570delAAC (p.Asn190del) and c.979T > C (p.Phe327Leu), confirmed the diagnosis of HPP. She subsequently had a short stature of less than -2.0 SD. ERT was started at the age of 4 years for short stature. She experienced gradual alleviation in fatigue after the initiation of ERT.

\section{Case 10: 2-year-old female patient}

The patient had prominently shorter limbs than normal since the fetal period and was born at 38 weeks and 3 days of gestation. She had severe respiratory failure immediately after birth and was therefore intubated. Blood test results after birth revealed a low serum ALP level of 8 IU/L (reference value for this age: $530-1,610 \mathrm{IU} / \mathrm{L}$ ). Consequently, she was clinically diagnosed as having HPP and was started on ERT and vitamin B6 supplements on day 0 . A genetic test later confirmed $A L P L$ variants, c.1333T > C (p.Ser445Pro) and c.1559delT (p.Leu520fs), and a diagnosis of HPP. The patient has sensorineural hearing loss that is gradually improving. She needs respiratory support during the night, but the respirator can be taken off during the daytime. She can pull herself up at the age of 2 years. Although she still has severe short stature, her height increased from $35.0 \mathrm{~cm}(-6.5 \mathrm{SD})$ to $72.3 \mathrm{~cm}(-4.8 \mathrm{SD})$ in 2 years and 4 months after ERT initiation.

To summarize, our case series reports the details of ERT experience in ten HPP patients of 9 families from January 2015 to November 2019 (median [interquartile range] age 11.0 years [7.6-12.5] years; $60 \%$ male patients) (Table 2). There was one case of perinatal lethal form of HPP, two cases of perinatal benign form, six cases of childhood form, and one case of odontohypophophatasia. The most common symptom at onset was bone abnormalities (four out of ten patients). The most common symptom during the clinical course of the disease was also bone abnormalities (eight out of ten patients). Two patients (cases 8 and 9) had calcification in the kidneys bilaterally. All ten patients had low serum ALP levels as compared with the age-matched reference range before ERT. 
Table 2

Clinical findings and laboratory values before and after* enzyme replacement therapy (ERT)

\begin{tabular}{|c|c|c|c|c|c|c|c|c|c|c|}
\hline Case & $\begin{array}{l}\text { Height[cm] } \\
\text { (SD score) }\end{array}$ & $\begin{array}{l}\text { Improvement in clinical } \\
\text { findings }\end{array}$ & $\begin{array}{l}\text { ALP } \\
{[\text { IU/L] }}\end{array}$ & $\begin{array}{l}\text { PLP } \\
\text { [nmol/L] }\end{array}$ & $\begin{array}{l}\mathrm{PL} \\
{[\mathrm{nmol} / \mathrm{L}]}\end{array}$ & $\begin{array}{l}\text { PLP/PL } \\
\text { (Reference) }\end{array}$ & $\begin{array}{l}\text { PEA } \\
\mathrm{Cr} \\
{[\mu \mathrm{mol}} \\
/ \mathrm{g} \\
\mathrm{Cr}]\end{array}$ & $\begin{array}{l}\text { 6MWT } \\
\text { [meter] }\end{array}$ & $\begin{array}{l}\begin{array}{l}\text { Bone } \\
\text { density }\end{array} \\
{\left[\mathrm{g} / \mathrm{cm}^{2}\right]} \\
\text { (SD } \\
\text { score) }\end{array}$ & $\begin{array}{l}\text { Adverse } \\
\text { effects }\end{array}$ \\
\hline 1 & $\begin{array}{l}103.7(-0.8 \text { SD }) / 116.5 \\
(-0.5 \text { SD })\end{array}$ & $\begin{array}{l}\text { Pain alleviation } \\
\text { Growth in height } \\
\text { 6MWT improvement }\end{array}$ & $197 / 12977$ & $\begin{array}{l}316.1 / \\
22.9\end{array}$ & $\begin{array}{l}22.2 / \\
37.9\end{array}$ & $\begin{array}{l}24.1 / 1 \\
(1.6-3.3)\end{array}$ & $\begin{array}{l}0.14 \\
/ \\
0.11\end{array}$ & $\begin{array}{l}350 / \\
400\end{array}$ & $\begin{array}{l}0.909 \\
(+6.0) \\
/ 0.911 \\
(+6.0)\end{array}$ & - \\
\hline 2 & $\begin{array}{l}124.4(-2.0 \text { SD }) / 135.7 \\
(-2.0 \text { SD })\end{array}$ & $\begin{array}{l}\text { Pain alleviation } \\
6 \mathrm{MWT} \text { improvement }\end{array}$ & $400 / 32956$ & $\begin{array}{l}164.4 / \\
3.2\end{array}$ & $\begin{array}{l}49.1 / \\
8.9\end{array}$ & $\begin{array}{l}3.4 / 0.4 \\
(1.2-2.5)\end{array}$ & $\begin{array}{l}0.02 \\
/ \\
0.08\end{array}$ & $\begin{array}{l}380 / \\
433\end{array}$ & $\begin{array}{l}0.554 \\
(-2.8) \\
/ 0.578 \\
(-2.7)\end{array}$ & प \\
\hline 3 & $\begin{array}{l}73.8(-2.0 \mathrm{SD}) / 86.9 \\
(-1.8 \mathrm{SD})\end{array}$ & $\begin{array}{l}\text { Cessation of premature } \\
\text { teeth loss } \\
\text { Growth in height }\end{array}$ & $79 / 24700$ & $\begin{array}{l}2293 / \\
137.1\end{array}$ & $39 / 96$ & $\begin{array}{l}58.7 / 1.4 \\
(1.6-3.3)\end{array}$ & $\begin{array}{l}0.5 \\
/ \\
0.18\end{array}$ & - & $\begin{array}{l}0.266 \\
(-0.6) \\
/-\end{array}$ & ૫ \\
\hline 4 & $\begin{array}{l}142.5(-0.3 \mathrm{SD}) / 145.2 \\
(-0.5 \mathrm{SD})\end{array}$ & Pain alleviation & $421 / 10274$ & 100.8 / - & $19.5 /-$ & $\begin{array}{l}5.2 /- \\
(1.9-5.3)\end{array}$ & $\begin{array}{l}0.019 \\
\text { / } \\
-\end{array}$ & 330 / - & $\begin{array}{l}1.008 \\
(-2.0) \\
/-\end{array}$ & - \\
\hline 5 & $\begin{array}{l}126.6(-1.9 \mathrm{SD}) / 142.0 \\
(-1.4 \mathrm{SD})\end{array}$ & $\begin{array}{l}\text { Pain alleviation } \\
\text { Growth in height }\end{array}$ & $359 / 22743$ & $\begin{array}{l}108.2 / \\
21.9\end{array}$ & $\begin{array}{l}17.5 / \\
43.5\end{array}$ & $\begin{array}{l}6.2 / 0.5 \\
(1.9-5.3)\end{array}$ & $\begin{array}{l}0.03 \\
/ \\
0.03\end{array}$ & 505 / - & $\begin{array}{l}0.974 \\
(+2.2) \\
/-\end{array}$ & प \\
\hline 6 & $\begin{array}{l}154.5(-0.7 \text { SD }) / 154.4 \\
(-0.7 \text { SD })\end{array}$ & $\begin{array}{l}\text { Alleviation of pain } \\
\text { and fatigue }\end{array}$ & $135 / 24675$ & $-/ 3.0$ & $-/ 4.1$ & $\begin{array}{l}-/ 0.7 \\
(1.9-5.3)\end{array}$ & $\begin{array}{l}0.08 \\
/-\end{array}$ & 336 / - & $\begin{array}{l}0.873 \\
(-1.8) \\
/ 0.873 \\
(-1.3)\end{array}$ & - \\
\hline 7 & $\begin{array}{l}96.8(-1.2 \text { SD) / } 102.2 \\
(-1.3 \text { SD })\end{array}$ & $\begin{array}{l}\text { Cessation of premature } \\
\text { teeth loss }\end{array}$ & $113 / 4051$ & $\begin{array}{l}1938 / \\
152\end{array}$ & $\begin{array}{l}33 / \\
72.6\end{array}$ & $\begin{array}{l}58.7 / 2.1 \\
(1.6-3.3)\end{array}$ & $\begin{array}{l}41.5 \\
/ \\
13.6\end{array}$ & - & $\begin{array}{l}0.362 \\
(-2.3) \\
/-\end{array}$ & - \\
\hline 8 & $\begin{array}{l}155.0(-2.5 \mathrm{SD}) / 156.6 \\
(-2.4 \mathrm{SD})\end{array}$ & 6MWT improvement & $103 / 44368$ & $-/ 37.1$ & $-/ 185.5$ & $\begin{array}{l}-/ 0.2 \\
(1.9-5.3)\end{array}$ & $\begin{array}{l}0.05 \\
\text { l } \\
0.015\end{array}$ & $\begin{array}{l}420 / \\
560\end{array}$ & $\begin{array}{l}0.685 \\
(-3.8) \\
/ 0.718 \\
(-3.7)\end{array}$ & प \\
\hline 9 & $\begin{array}{l}※ 103.0(-2.4 \mathrm{SD}) / \\
118.3(-2.3 \mathrm{SD})\end{array}$ & Alleviation of fatigue & $157 / 25634$ & $-/ 15.7$ & $-/ 34.3$ & $\begin{array}{l}-/ 0.5 \\
(1.9-5.3)\end{array}$ & $\begin{array}{l}0.12 \\
/ \\
0.09\end{array}$ & $273 /-$ & $\begin{array}{l}0.478 \\
\text { (N.R.) } \\
/ 0.572 \\
(-1.7)\end{array}$ & ] \\
\hline 10 & $\begin{array}{l}35.0(-6.5 \mathrm{SD}) / 72.3(- \\
4.8 \mathrm{SD})\end{array}$ & $\begin{array}{l}\text { Respiratory condition } \\
\text { improvement } \\
\text { QOL improvement } \\
\text { Growth in height }\end{array}$ & $8 / 17720$ & $-/ 27$ & - / 37.6 & $\begin{array}{l}-/ 0.7 \\
(1.2-2.5)\end{array}$ & $\begin{array}{l}-/ \\
0.29\end{array}$ & - & $\begin{array}{l}- \\
\text { / } 0.583 \\
\text { (N.R.) }\end{array}$ & ? \\
\hline *Valu & fore the slash indicate & values before the start & RT, and af & e slash & cate th & ues after & 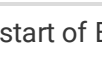 & $\mathrm{T}$. & & \\
\hline $\begin{array}{l}\text { ALP: } \\
\text { phos }\end{array}$ & $\begin{array}{l}\text { line phosphatase; ERT: } \\
\text { e; } 6 \mathrm{MWT} \text { : 6-minute wall }\end{array}$ & $\begin{array}{l}\text { yme replacement therap } \\
\text { st }\end{array}$ & R.: no ref & e; PEA & sphati & lanolamin & L: pyr & al, PL & /ridoxal & \\
\hline
\end{tabular}

Genetic analysis showed that eight out of ten patients had compound heterozygosity, and two patients (cases 2 and 4 ) had only one heterozygous variant. Five out of ten patients had the c.1559delT (p.Leu520fs) variant, which is common in Japan [6]. In contrast, only two patients had the c.979T > C (Phe310Leu) variant, which is also common in Japan [6].

All patients showed improvements in clinical symptoms after ERT such as increase in height, pain alleviation, cessation of premature deciduous tooth loss, better performance in the 6-minute walk test, or improvement in respiratory insufficiency. All five patients (cases 1, 2, 4, 5, and 6) who experienced pain in extremities had alleviation of pain after ERT initiation. Two patients (cases 3 and 7) with premature loss of deciduous teeth, with the roots intact, did not lose teeth prematurely after initiation of ERT. Clinical improvements in patients with the prenatal benign form (cases 8 and 9) were increased distance in the 6minute walk test and alleviation of fatigue. Case 10 had a severe short stature with a height of $72.3 \mathrm{~cm}(-4.8$ SD) at 2 years and 4 months of age even after 
the initiation of ERT (her height was - 6.5 SD at birth). There was improvement in respiratory insufficiency, and motor, mental, and auditory development progressed gradually. Changes in biochemical data after the initiation of ERT showed a tendency for PLP and PEA to decrease and PL to increase. These changes are consistent with the pathophysiology of the disease.

In three patients (cases 5, 6, and 9), ERT was either discontinued temporarily or the total dose was reduced owing to injection site reaction or fever. Patient 5 resumed an adequate dose of ERT 6 months after dose reduction. Patient 6 continues to receive ERT twice a week, instead of three times a week owing to the pain with ERT injection. Patient 9 resumed ERT for the first time 1 year and 10 months after stopping ERT.

\section{Discussion}

This is the largest single-center cohort study in Asia describing the clinical course of patients with HPP treated by ERT. In particular, we have elucidated the efficacy of ERT in childhood-onset HPP. However, there were some limitations in our study. First, effectiveness of ERT in reducing pain was assessed based on the subjective responses of the patients or their parents. Second, our study group was a single-center cohort. Nevertheless, we believed that presenting the clinical courses of HPP patients after ERT would benefit clinicians treating patients with HPP.

Although the efficacy of ERT in the perinatal and infantile form of HPP has been demonstrated in a Japanese clinical trial, the number of patients with childhood and adult form of HPP was comparatively lower [11]. There are currently no adequate biomarkers available to evaluate the effectiveness of ERT, which necessitates the close monitoring of improvement in clinical findings of each case [16]. In our study, clinical findings of the patients such as pain, short height, premature loss of teeth, poor performance in the 6-minute walk test, or respiratory insufficiency were alleviated after initiating ERT. Conversely, clinical improvement of signs (6-minute walk test or the level of fatigue) in patients with the prenatal benign form (cases 8 and 9) seemed less obvious than in patients with the childhood form of HPP. The reduced effectiveness of ERT can be attributed to the differences in disease forms or the late start of treatment. Further studies are needed to explore the improvement of clinical signs in different forms of HPP after ERT.

\section{Case 10}

with perinatal lethal HPP continued to have severe short stature even though the growth rate improved considerably after the initiation of ERT (from - 6.5 SD to $-4.8 \mathrm{SD}$ ). We could not draw a comparison between the clinical signs before and after the initiation of ERT with respect to case 10

as ERT was initiated immediately after birth. The natural prognosis of perinatal lethal HPP is poor, with death occurring within 1 year [17]. Therefore, we can say that ERT improved the patient's prognosis and quality of life.

HPP is usually inherited in an autosomal recessive manner; however, an autosomal dominant genetic form has been also recognized. In general, the autosomal recessive form is prevalent in more severe phenotypes, while the autosomal dominant form is prevalent in milder phenotypes. In our study, two patients (cases 2 and 4) deserve additional attention. Even though they only had a heterozygous variant that was reported as an autosomal recessive form of HPP, c.1559delT (p.Leu520fs) and c.984_986delCTT (p.Phe327del) in cases 2 and 4, respectively, their symptoms were relieved through ERT. Case 2 was very responsive to ERT (Additional File 1). In general, dominant inheritance is caused by a dominant-negative effect (DNE), gain of function, or haploinsufficiency. Owing to the allosteric properties of TNSALP, dominant HPP is believed to result from DNE [18]. Although the homozygous variant of c.1559delT (p.Leu520fs) or c.984_986delCTT (p.Phe327del) has quite a low enzymatic activity, a heterozygous variant of either c.1559delT (p.Leu520fs) or c.984_986delCTT (p.Phe327del) does not show DNE in vitro study [19]. Conversely, it is known that patients with HPP, who have a heterozygous variant of the autosomal recessive genetic form of HPP without DNE, have HPP symptoms [20]. In a Japanese clinical trial, a heterozygous c.1559delT (p.Leu520fs) variant caused the patient to exhibit symptoms of the adult form of HPP, and symptoms such as myalgia and arthralgia were improved through ERT [11]. Recent reports suggest heterogeneity of the genotype-phenotype correlation and other genetic or environmental factors modulating HPP phenotype [10, 17]. A study reported that ERT was initiated in a patient with odontohypophosphatasia who had a heterozygous missense variant, c.1183A > T (p.Ile395Phe), in the ALPL gene [21]. However, in this report, ERT did not demonstrate significant efficacy. To the best of our knowledge, our study is the first report that shows the efficacy of ERT in patients with the childhood form of HPP and having a heterozygous variant of the ALPL gene.

Although genetic analysis is recommended to diagnose HPP patients, a detailed patient history and clinical examination are the crucial first steps. There might be patients with heterozygous $A L P L$ variants like case 2 who respond to ERT. We should comprehensively consider the indications for starting ERT in patients with HPP and closely monitor their clinical improvement while evaluating the safety of ERT for each patient.

\section{Conclusion}

We reported the largest single-center cohort in Asia describing the clinical course of patients with HPP, treated with ERT. Every patient benefited from ERT. A noteworthy observation was that even if patients have HPP symptoms with only heterozygous variants, ERT can still be a valuable therapeutic option. We will continue to conduct future studies with long-term follow-up periods to investigate the efficacy of ERT in patients with HPP.

\section{Abbreviations}

ERT, enzyme replacement therapy;

HPP, hypophosphatasia;

PEA, phosphoethanolamine; 
PLP, pyridoxal 5' phosphate;

TNSALP, tissue-nonspecific alkaline phosphatase;

SD, standard deviation

\section{Declarations}

Ethics approval and consent to participate: This is an observational retrospective patient report that did not involve any research-based patient intervention. All diagnostic procedures and treatment protocols were based on established protocols intended to diagnose and treat the patients. No aspect of the case series is in contradiction with the Helsinki Declaration of 1975, as revised in 2000. The assay of pyridoxal phosphate and pyridoxal was approved by the Research Ethics Board at Okayama University Hospital (Approval No. 1603-012). Written informed consent for publication of the data and for performing measurements of PLP and PL were obtained from the patients or patient's parents (in case of patients below 18 years of age).

Consent for publication: Written informed consent for publication of the data, measurements of PLP and PL, and the video record of patient 2 was obtained from the patient's parents.

Availability of data and materials: The datasets used and/or analyzed during the current study are available from the corresponding author on reasonable request.

Competing interests: All authors declare that they have no competing interests.

Funding: No funding was received for this study.

Authors' contributions: YS, TW, and MT drafted the article. MS, TM, TE, TF, A.M, KI, and TT critically reviewed the manuscript. TA measured pyridoxal 5'phosphate and pyridoxal, and critically reviewed the manuscript. KM is the acting guarantor. All authors have read and approved the final manuscript.

Acknowledgements: We would like to thank Editage (www.editage.com) for English language editing.

\section{References}

1. Mornet E. Hypophosphatasia. Orphanet J Rare Dis. 2007;2:40. https://doi: 10.1186/1750-1172-2-40.

2. Weiss MJ, Ray K, Henthorn PS, Lamb B, Kadesch T, Harris H. Structure of the human liver/bone/kidney alkaline phosphatase gene. J Biol Chem. 1988;263:12002-10. https://www.sciencedirect.com/science/article/pii/S0021925818378852?via\%3Dihub.

3. Seefried L, Kishnani P, Moseley S, Denker AE, Watsky E, Whyte MP et al. Pharmacodynamics of asfotase alfa in adults with pediatric-onset hypophosphatasia. Bone. 2021;142:115664. https://doi: 10.1016/j.bone.2020.115664.

4. Millan JL, Whyte MP. Alkaline phosphatase and hypophosphatasia. Calcif Tissue Int. 2016;98:398-416. https://doi: 10.1007/s00223-015-0079-1.

5. Wenkert D, McAlister WH, Coburn SP, Zerega JA, Ryan LM, Ericson KL, et al. Hypophosphatasia: nonlethal disease despite skeletal presentation in utero (17 new cases and literature review). J Bone Miner Res. 2011;26:2389-98. https://doi: 10.1002/jbmr.454.

6. Michigami T, Uchihashi T, Suzuki A, Tachikawa K, Nakajima S, Ozono K. Common mutations F310L and T1559del in the tissue-nonspecific alkaline phosphatase gene are related to distinct phenotypes in Japanese patients with hypophosphatasia. Eur J Pediatr. 2005;164:277-82. https://doi: $10.1007 / \mathrm{s} 00431-004-1612-9$.

7. Michigami T, Ohata Y, Fujiwara M, Mochizuki H, Adachi M, Kitaoka T, et al. Clinical practice guidelines for hypophosphatasia. Clin Pediatr Endocrinol. 2020;29:9-24. https://doi: 10.1297/cpe.29.9.

8. Daniel AB, Saraff V, Shaw NJ, Yates R, Mughal MZ, Padidela R. Healthcare resource utilization in the management of hypophosphatasia in three patients displaying a spectrum of manifestations. Orphanet J Rare Dis. 2018;13:142. https://doi: 10.1186/s13023-018-0869-4.

9. Whyte MP. Hypophosphatasia - aetiology, nosology, pathogenesis, diagnosis and treatment. Nat Rev Endocrinol. 2016;12:233-46. http://doi: 10.1038/nrendo.2016.14.

10. Mornet E, Taillandier A, Domingues C, Dugour SA, Benaloun E, Lavaud N, et al. Hypophosphatasia: a genetic-based nosology and new insights in genotypephenotype correlation. Eur J Hum Genet. 2021;29:289-99. https://doi: 10.1038/s41431-020-00732-6.

11. Kitaoka T, Tajima T, Nagasaki K, Kikuchi T, Yamamoto K, Michigami T, et al. Safety and efficacy of treatment with asfotase alfa in patients with hypophosphatasia: Results from a Japanese clinical trial. Clin Endocrinol. 2017;87:10-19. https://doi: 10.1111/cen.13343.

12. Tanaka T, Yamashita A, Ichihara K. Reference intervals of clinical tests in children determined by a latent reference value extraction method (in Japanese). J Jpn Pediatr Soc. 2008;112:1117-32. 
13. Akiyama T, Hayashi Y, Hanaoka Y, Shibata T, Akiyama M, Tsuchiya H, et al. Pyridoxal 5'-phosphate, pyridoxal, and 4-pyridoxic acid in the paired serum and cerebrospinal fluid of children. Clin Chim Acta. 2017;472:118-22. https://doi.org/10.1016/j.cca.2017.07.032.

14. Japanese Ministry of Health, Labour and Welfare. National growth survey on preschool children, Tokyo, Japan (in Japanese).

2000. https://www.mhlw.go.jp/houdou/0110/h1024-4.html. Accessed on 25 June 2021.

15. Japanese Ministry of Education, Culture, Sports, Science and Technology. Report of the national growth survey of normal Japanese children, 5-17 years of age, Tokyo, Japan (in Japanese). 2003. https://www.e-stat.go.jp/stat-search/files?

page $=1 \&$ layout $=$ datalist $\&$ toukei $=00400002 \&$ tstat $=000001011648 \&$ cycle $=0 \&$ tclass $1=000001022251 \&$ tclass $2=000001022252 \&$ stat_infid $=000001199546 \&$ tclas Accessed on 25 June 2021.

16. Kishnani PS, Rush ET, Arundel P, Bishop N, Dahir K, Fraser W, et al. Monitoring guidance for patients with hypophosphatasia treated with asfotase alfa. Mol Genet Metab. 2017;122:4-17. https://doi: 10.1016/j.ymgme.2017.07.010.

17. Leung EC, Mhanni AA, Reed M, Whyte MP, Landy H, Greenberg CR. Outcome of perinatal hypophosphatasia in manitoba mennonites: a retrospective cohort analysis. JIMD Rep. 2013;11:73-8. https:// doi: 10.1007/8904_2013_224.

18. Mornet E. Hypophosphatasia. Metabolism. 2018;82:142-55. https://doi: 10.1016/j.metabol.2017.08.013.

19. Del Angel G, Reynders J, Negron C, Steinbrecher T, Mornet E. Large-scale in vitro functional testing and novel variant scoring via protein modeling provide insights into alkaline phosphatase activity in hypophosphatasia. Hum Mutat. 2020;41:1250-62. https://doi: 10.1002/humu.24010.

20. Taillandier A, Domingues C, Dufour A, Debiais F, Guggenbuhl P, Roux C, et al. Genetic analysis of adults heterozygous for ALPL mutations. J Bone Miner Metab. 2018;36:723-33. https://doi: 10.1007/s00774-017-0888-6.

21. Takagi M, Kato S, Muto T, Sano Y, Akiyama T, Takagi J, et al. Odontohypophosphatasia treated with asfotase alfa enzyme replacement therapy in a toddler: a case report. Clin Pediatr Endocrinol. 2020;29:115-8. https://doi: 10.1297/cpe.29.115.

\section{Supplementary Files}

This is a list of supplementary files associated with this preprint. Click to download.

- Additionalfile114thJuly20210JRD.pptx 